\title{
Histopathological Changes in Multiple Fetal Tissues Exposed In-Utero to Zidovudine
}

Rajlakshmi Chongtham *, Asima Bhattacharyya and Mohan Kumar

Regional Institute of Medical Sciences (RIMS) Imphal, Manipur, India

*Corresponding author: Rajlakshmi Chongthama, Regional Institute of Medical Sciences (RIMS) Imphal, Manipur India; E-mail: chongthamrajlakshmi@yahoo.in

Received date: July 26, 2014; Accepted date: October 30, 2014; Published date: November 11, 2014

Copyright: (c) 2014 Chongthama R, et al. This is an open-access article distributed under the terms of the Creative Commons Attribution License, which permits unrestricted use, distribution, and reproduction in any medium, provided the original author and source are credited.

\begin{abstract}
Objective: Zidovudine, the first antiretroviral drug is used to prevent vertical transmission of HIV infection. Without any adequate proof of its safety to fetus, the drug was administered to pregnant women. The present experiment aims to study at the light microscopic level, the effect of zidovudine in fetus exposed in-utero to the drug.

Material and method: Sixty Swiss mice were divided into two groups of control $(n=20)$ and experimental $(n=40)$. A dose of $50 \mathrm{mg} / \mathrm{kg} /$ day was administered orally to experimental group and an equivalent amount of normal saline to control group. Drug was administered from day 8 to day 16 of gestation and on day 19 the animal was sacrificed. Fetus collected after laparotomy were fixed in $10 \%$ neutral formalin and then subjected to light microscopic study to assess the histopathological changes. H\&E stained sections of liver, lung, kidney, brain and maternal ovary was analysed.

Result: Fatty degeneration of liver, degenerative changes in kidney section, dilatation of alveoli with thinning of alveolar wall, microcystic degeneration in cerebral cortex was observed. The maternal ovary of experimental group had small corpus luteum.

Conclusion: Multiple tissues are affected by in-utero administration of ZDV. Further study at ultrastructural level is needed.
\end{abstract}

Keywords: Zidovudine; Histopathology; Fetus; In-utero; Kidney; Brain

\section{Introduction}

Zidovudine (3'-azido 3'-deoxythymidine, azidothymidine, ZDV) is the first antiretroviral agent used to treat patients suffering from HIVAIDS. Since 1994, this drug is also used to HIV positive pregnant women to prevent vertical transmission of the virus during pregnancy [1]. ZDV was an indispensible prophylactic drug especially to HIV positive pregnant women after a US Public Health Services Task Force recommended its use for reduction of perinatal HIV-1 transmission [2]. Despite the dramatic increase of ZDV in the perinatal use of ZDV, information about the microscopic consequences of use of ZDV to fetus, infants and children who were exposed to the antiretroviral drug in- utero is still meager [3-5]. The present study was therefore, carried out to investigate the prenatal effect of $\mathrm{ZDV}$ in fetus at the light microscopic level. In fact, the article may be considered as the continuation of teratogenic effect of ZDV published earlier by us [6-8].

\section{Material and Methods}

The present study was conducted in the Department of Anatomy, Institute of Medical Sciences, Banaras Hindu University, Varanasi on 60 successfully pregnant Swiss mice. A room temperature of $25^{\circ} \mathrm{C} \pm$ $2^{\circ} \mathrm{C}$ with relative humidity of $45-55 \%$ and $12 \mathrm{hr}$ light-dark cycle was maintained. Animals were fed with readymade rodent pellet diet and water ad libitum. Zidovudine was purchased from pharmacy through antiretroviral therapy (ART) Centre, Institute of Medical Sciences,
BHU, Varanasi. Zidovudine Oral Solution USP (Zidovir), manufactured by CIPLA Ltd., Goa, India was used. One milliliter of oral solution contained $10 \mathrm{mg}$ of active zidovudine. The pregnant mice were divided into two groups:

Group A: Control group $(\mathrm{n}=25)$

Group B: Experimental group $(\mathrm{n}=40)$

A dose of $50 \mathrm{mg} / \mathrm{kg} /$ day of zidovudine were administered orally to the experimental pregnant mice and an equivalent amount of normal saline was administered to the control group. First dose commenced on gestational day 8 and continued daily and the last dose was administered on gestational day 16. Mice were sacrificed on gestational day 19 by cervical dislocation. Fetus were collected by laparotomy. The entire fetus was fixed in $10 \%$ neutral formalin for not less than 10 days. One fetus per litter was randomly selected for microscopic study. Fetal tissues used in the study were kidney, liver, lung, brain and maternal ovary was studied. A $7 \mu \mathrm{m}$ thick section was cut, stained with H\&E and examined by light microscopy.

A prior permission was taken from the Institutional Animal Ethics Committee.

\section{Result}

\section{Outcome of pregnancy in experimental group}

Out of 40 experimental mice, 19 pregnant mice failed to gain weight after 5-6 days of treatment. These mice were observed for few more 
Citation: Chongtham R, Bhattacharyya A, Kumar M (2014) Histopathological Changes in Multiple Fetal Tissues Exposed In-Utero to Zidovudine.

Page 2 of 5

days and sacrificed after constant weight was observed on $16^{\text {th }}$ or $17^{\text {th }}$ day of gestation. All the 19 (47.5\%) mice had 100\% fetal resorption characterized by dilated and highly vascular uterine horns (Figure 1). Three pregnant mice had bleeding per vagina on day $13^{\text {th }}$ day of gestation. They were sacrificed and showed teratogenic changes in the fetus [6]. Remaining 18 (35\%) pregnant mice carried the pregnancy to term which eighty six implantations were observed compared to 168 in the control group. The litter size were $4.53 \pm 0.99$ in the experimental group as compared to $6.5 \pm 1.2$ in the control (Figure 2 and Table 1).
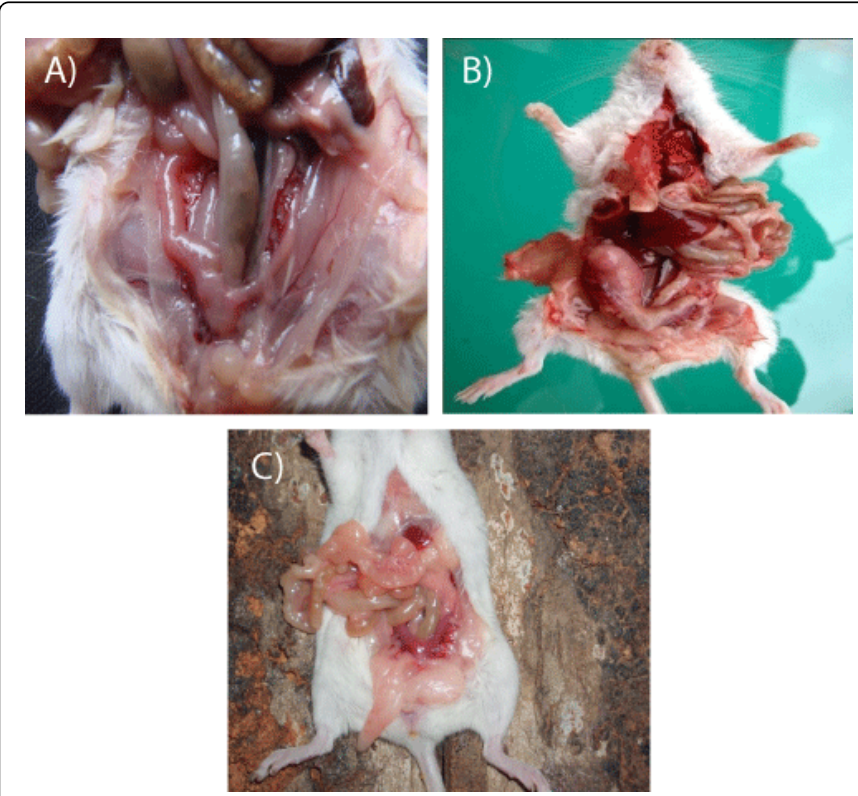

Figure 1: Dilated and vascular uterine tube in total resorption of fetus in experimental group.
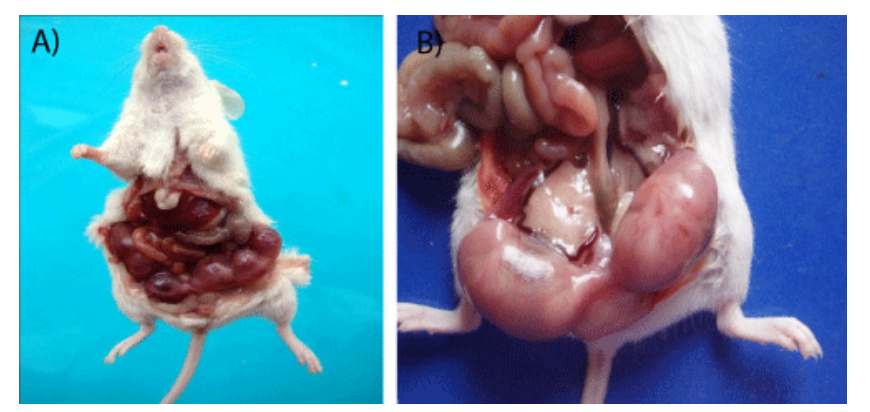

Figure 2: A) Control pregnant mouse with eight fetuses in situig. B) Experimental mouse with only two foetuses.

\begin{tabular}{|l|l|l|}
\hline & Control & Treated \\
\hline Total pregnant mice & 20 & 40 \\
\hline $\begin{array}{l}\text { No. of pregnant mice successfully carrying } \\
\text { to term, GD 19 (\%) }\end{array}$ & $20(100 \%)$ & $18(35 \%)$ \\
\hline $\begin{array}{l}\text { No. of pregnant mice with complete fetal } \\
\text { resorption (\%) }\end{array}$ & 0 & $19(47.5 \%)$ \\
\hline
\end{tabular}

\begin{tabular}{|l|l|l|}
\hline $\begin{array}{l}\text { No. of pregnant mice with vaginal bleeding } \\
\text { during pregnancy(\%) }\end{array}$ & 0 & $3(2.56 \%)^{*}$ \\
\hline No. of implantation sites & 168 & 86 \\
\hline Total live fetuses & 166 & 77 \\
\hline No. of dead fetus (\%) & 0 & $2(2.56 \%)$ \\
\hline No. of resorbed implantion site (\%) & $2(2.7 \%)$ & $7(8.9 \%)$ \\
\hline No. of growth retarded fetuses (\%) & $19(11.3 \%)$ & $54(70.1 \%)$ \\
\hline No. of fetus with birth defects (\%) & 0 & $3(3.91 \%)^{*}$ \\
\hline Litter size & $6.5 \pm 1.2$ & $4.53 \pm 0.99$ \\
\hline
\end{tabular}

Table 1: Zidovudine administration ( $50 \mathrm{mg} / \mathrm{kg} /$ day) from GD8 to GD 16 and outcome o pregnancy ${ }^{\star}$ ref 6 .

\section{Maternal weight gain during pregnancy}

Mean weight of pregnant mice in the experimental group on day 0 of gestation was $25.91 \pm 2.04$ as compared to $25.58 \pm 3.41$ in the control group. Mean weight of pregnant mice on day 19 of gestation were $34.62 \pm 3.63$ and $37.28 \pm 5.03$ in experimental and control group respectively. However, the differences in the gain in weight were statistically not significant (Table 2).

\begin{tabular}{|c|c|c|c|c|}
\hline & Group & $\begin{array}{l}\text { Total pregnant } \\
\text { mice }\end{array}$ & $\begin{array}{l}\text { Body weight in gm } \\
\text { (mean } \pm \mathrm{SD} \text { ) }\end{array}$ & $p$-value \\
\hline \multirow{2}{*}{$\begin{array}{l}\text { Body } \\
\text { weight on } \\
\text { GD0 }\end{array}$} & Control & 20 & $25.58 \pm 3.41$ & \multirow[t]{2}{*}{$>0.05$} \\
\hline & Treated & 18 & $25.91 \pm 2.03$ & \\
\hline \multirow{2}{*}{$\begin{array}{l}\text { Body } \\
\text { weight on } \\
\text { GD19 }\end{array}$} & Control & 20 & $37.28 \pm 5.03$ & \multirow[t]{2}{*}{$>0.05$} \\
\hline & Treated & 18 & $34.62 \pm 3.63$ & \\
\hline
\end{tabular}

Table 2: Weight gained by the control and experimental pregnant mice from GD8 to GD16.

\section{Histopathological changes in fetal tissues exposed in-utero to Zidovudine}

Light microscopic study was based on random selection of two fetus per litter of the experimental $(n=36)$ and one or two fetus per litter of the control group $(n=30)$.

Liver: Fatty degeneration was observed in the experimental group as compared to normal histology in the control (Figure 3).

Kidney: Marked degenerative changes were observed in the glomerulus, both the layers of Bowman's capsule as well as the tubules. Control group showed no change in the histological architecture of kidney (Figure 4).

Lungs: Alveoli were dilated and some areas of lung field showed rupture of alveoli in the experimental group. Normal lung parenchyma observed in the control group (Figure 5).

Brain: Microcystic degeneration was observed in the cerebral cortex in the experimental group. Sections were normal $\mathrm{n}$ the control group (Figure 6). 
Citation: Chongtham R, Bhattacharyya A, Kumar M (2014) Histopathological Changes in Multiple Fetal Tissues Exposed In-Utero to Zidovudine. J AIDS Clin Res 5: 373. doi:10.4172/2155-6113.1000373

Page 3 of 5

Maternal ovary: The size of the corpus luteum were small as well as less in number in the experimental group whereas the corpus luteum are large in the control group (Figure 7).

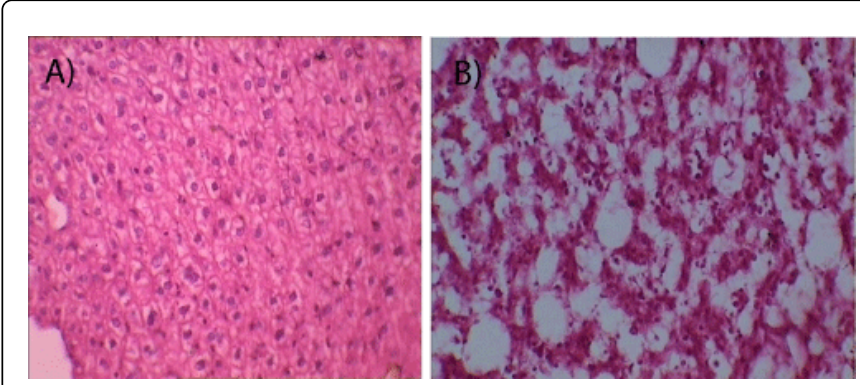

Figure 3: A) Photomicrograph of section of fetal liver (control), H\&E; 400X. B) Photomicrograph of section of fetal liver (experimental) showing disruption of normal lobular architecture with features of macro and micro steatosis (white arrow), H\&E; 400X.

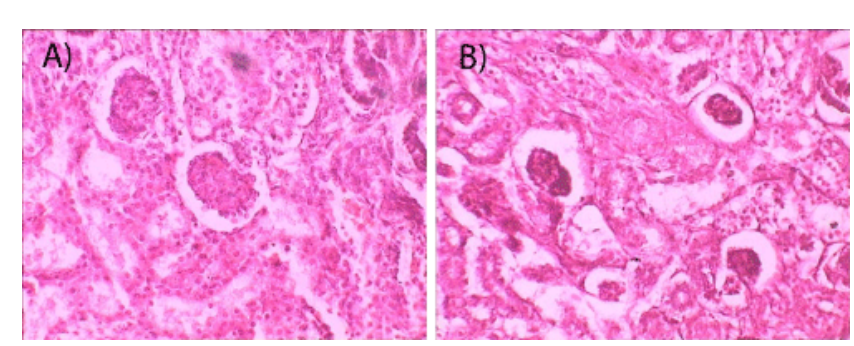

Figure 4: A) Photomicrograph of section of fetal kidney (control), H\&E; 400X. B) Photomicrograph of section of fetal kidney (experimental) showing features of glomerulosclerois (white arrow), mild tubular necrosis along with a few mixed inflammatory cellinfiltrates in the interstitium, H\&E; 400X.
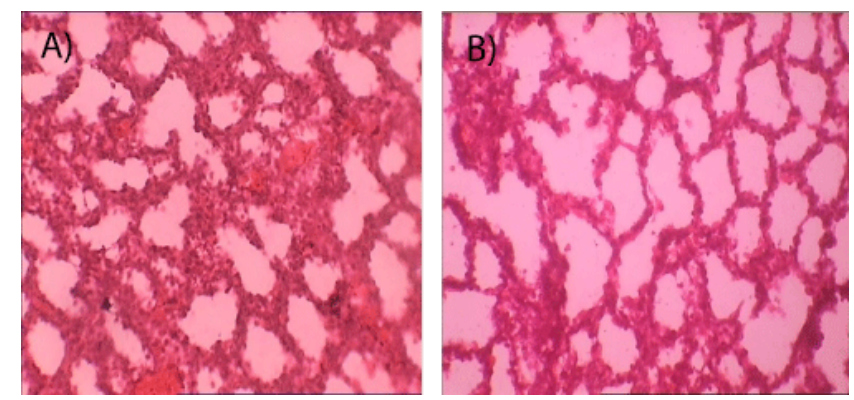

Figure 5: A) Photomicrograph of section of fetal lung (control), $\mathrm{H} \& \mathrm{E} ; 400 \mathrm{X}$. B) Photomicrograph of section of fetal lung (experimental) showing evidence of atelectasis, interstitial oedema with focal areas of type-2 pneumoyte hyperplasia (black arrow heads), H\&E; 400X.
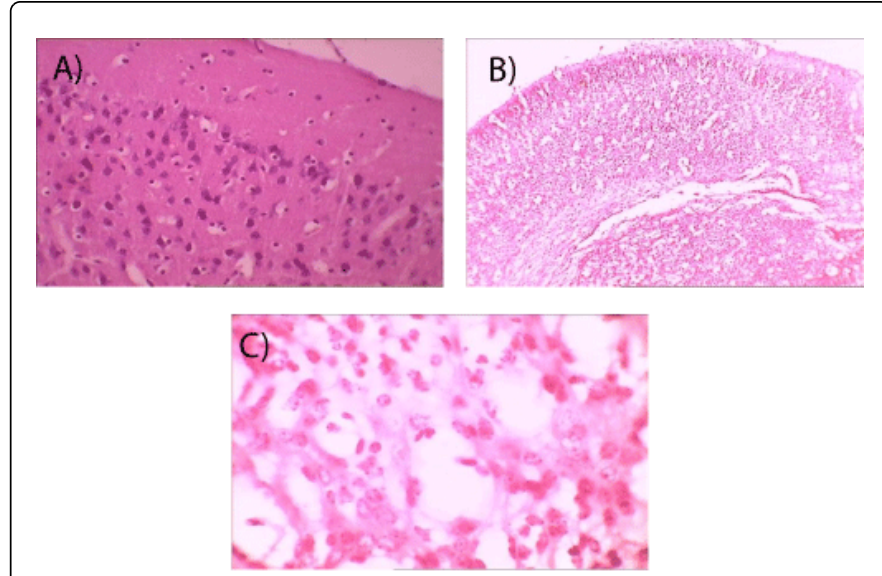

Figure 6: Photomicrograph of section of fetal brain (control), H\&E; 400X. Photomicrograph of section of fetal brain (experimental) showing microcystic degeneration (black arrow heads), H\&E; 400X \&1000X.
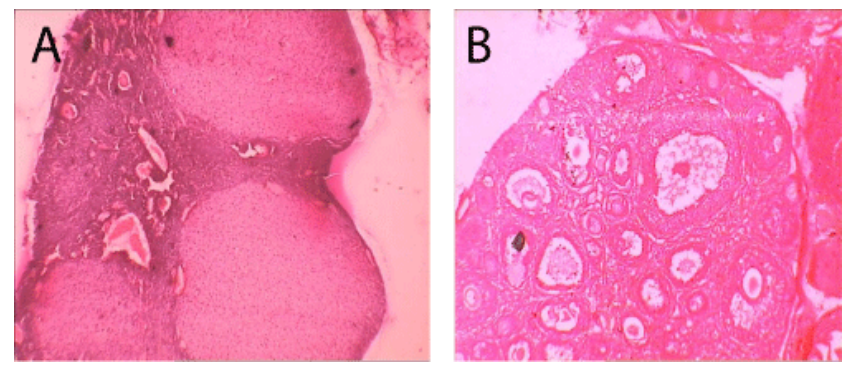

Figure 7: A) Photomicrograph of section of maternal ovary (control) with normal corpus luteum (white arrow), H\&E; 100X. B) Photomicrograph of section of maternal ovary (experimental) showing atretic corpusluteum (white arrow), H\&E; 100X.

\section{Discussion}

Histopathological changes observed in multiple tissues of fetus could be the result of the mechanism of action of Zidovudine. ZDV is structurally related to endogenous nucleoside thymidine, differing in the replacement of hydroxyl group at the 3'- position of the ribose ring with an unreactive azido (N3) group. Therefore, ZDV has a strong affinity for DNA polymerase $\beta$ and $\gamma$. Thus, it acts by inhibiting reverse transcriptase enzyme [9]. DNA polymerase $\alpha$ and $\beta$ are capable of incorporating ZDV-monophosphate into DNA and cause chain termination [10].

Preferential incorporation of ZDV into telomeric DNA and cause shortening from $22 \mathrm{~Kb}$ to $2 \mathrm{~Kb}$ in DNA of lung, liver and brain tissues from ZDV-exposed newborn mice [11]. Poirier et al. observed incorporation of ZDV into DNA of fetal liver; lung, heart, skeletal muscle, brain, testis and placenta were observed when ZDV was infused to pregnant rhesus monkeys which varied between 29 and 1944 molecules of ZDV/106 nucleotides. ZDV was also found to be threefold higher in fetal blood and amniotic fluid than those in maternal blood [12]. Bialkowska et al. were first to identify the oxidative damage to nuclear DNA in fetal liver and kidney tissues of 
pregnant swiss mice and patas monkeys. Increased level of 8-oxo-2'deoxyguanosine, a reactive oxygen species, may contribute to the mechanism of transplacental carcinogenesis [13]. In human samples too, Olivero et al. and Meng et al. observed incorporation of ZDV in DNA of cord blood cell of newborn infants exposed in-utero to ZDV by using anti-ZDV radioimmunoassay [14,15]. Using trypan blue exclusion technique, Slamenova et al. reported the cytotoxic effects of ZDV in human embryonic lung fibroblasts and colonic Caco- 2 cells. They observed that $3 \mathrm{hr}$ treatment of cells with ZDV was moderately cytotoxic for the cells [16].

We observed small litter size which is in consistent with previous researchers who observed small litter size in mice and rat $[17,18]$. In a cohort study in pregnant women an increased risk of low birth weight $(<1500 \mathrm{~g})$ in $2 \%$ of exposed infants and premature delivery in exposed fetuses was observed $[19,20]$.

Neurobehavioural changes reported by different authors [21,22] suggest a cerebral effect of ZDV. We had also observed neurobehavioural changes in the same experiment [7]. In- vitro study of brain cells from fetal mouse exposed to ZDV showed slightly more cytotoxic effect as compared to other tissues of the body - like limbbud or different organ rudiment [23]. Even a single exposure of 150 $\mathrm{mg} / \mathrm{kg} \mathrm{ZDV}$ along with tracer amounts of $14 \mathrm{C}-\mathrm{ZDV}$ in pregnant rats produced a higher concentration of ZDV in fetal brain than in spinal cord [24].

There are numerous reports on mitochondrial alteration in fetus and infants exposed in-utero to ZDV. One of the earliest to report observed visual impairment, respiratory and cardiac rhythm disorders, epilepsy, and deterioration of cognitive and psychomotor abilities in children exposed prenatally to ZDV [25]. In another study, mitochondrial DNA was observed to be damaged in liver tissues [26]. In yet another study of prenatal exposure of $40 \mathrm{mg} /$ day of ZDV in patas monkeys showed damage of cerebral mitochondria [27]. It was opined that affected mtDNA polymerase $\gamma$ can gradually lead to dysfunction and cellular toxicity. And, the clinical manifestations of the mitochondrial toxicity resemble those of inherited mitochondrial diseases like hepatic steatosis, lactic acidosis, myopathy, nephrotoxicity, peripheral neuropathy and panceatitis [28].

We observed myriad histopathological changes in multiple fetal tissues of mice which although could not be compared in to with the previous works done by numerous researchers, however, our result can project a composite picture of the side effect of ZDV affecting almost all tissues of the body. We would suggest an electron microscopic study of the same to confirm the ill effect of the drug in a more detail way in different species. Lastly, the gravity of the toxic effect of ZDV in children exposed perinatally to ZDV can be proven in years to come as the children born to mothers exposed to ZDV could be all below 20 years since it was recommended for use in 1994 only 2 .

\section{References}

1. Watts DH (2006) Treating HIV during pregnancy: an update on safety issues. Drug Saf 29: 467-490.

2. Centers for Disease Control and Prevention (CDC) (1995) Update: AIDS among women--United States, 1994. MMWR Morb Mortal Wkly Rep 44: 81-84.

3. DiMaio MF, Ting A, Hsu MT, Gil J, Kattan M (1995) Effect of zidovudine on human fetal lung development. Pediatr AIDS HIV Infect 6: 83-90.
4. Corcuera T, Alonso MJ, Picazo A, Gómez F, Roldán M, et al. (1996) Hepatic Morphological alterations induced by zidovudine (ZDV) in an experimental model. Pathol Res Pract 192: 182-187.

5. Omar RF, Gourde P, Désormeaux A, Tremblay M, Beauchamp D, et al. (1996) In vivo toxicity of foscarnet and zidovudine given alone or in combination. Toxicol Appl Pharmacol 139: 324-332.

6. Rajlakshmi C, Bhattacharyya A (2008) Teratogenic effects of Zidovudine in the developing mice. J Anat Soc India $57: 101-106$.

7. Rajlakshmi C, Trigunayat A, Bhattacharyya A, Pandey BL (2008) Neurobehavioural profile of F1 and F2 generation mice following one stage Zidovudine exposure through pregnancy and lactation. Annals of Neurosciences 15: 69-74

8. Rajlakshmi C, Roy JK, Rai AK, Bhattacharyya A, Pandey BL (2012) An unusual phenotypic and genotypic expression in F2 generation following one stage zidovudine exposure during pregnancy and lactation- an experiment in mice. J Toxicol Sci 37: 51-61.

9. Huang P, Farquhar D, Plunkett W (1990) Selective action of 3'-azido-3'deoxythymidine 5 '-triphosphate on viral reverse transcriptases and human DNA polymerases. J Biol Chem 265: 11914-11918.

10. Copeland WC, Chen MS, Wang TS (1992) Human DNA polymerases alpha and beta are able to incorporate anti-HIV deoxynucleotides into DNA. J Biol Chem 267: 21459-21464.

11. Olivero OA, Anderson LM, Diwan BA, Haines DC, Harbaugh SW, et al (1997) Transplacental effects of 3'-azido-2',3'-dideoxythymidine (AZT): tumorigenicity in mice and genotoxicity in mice and monkeys. J Natl Cancer Inst 89: 1602-1608.

12. Poirier MC, Patterson TA, Slikker W Jr, Olivero OA (1999) Incorporation of 3'-azido-3'-deoxythymidine (AZT) into fetal DNA and fetal tissue distribution of drug after infusion of pregnant late-term rhesus macaques with a human-equivalent AZT dose. J Acquir Immune Defic Syndr 22: 477-483.

13. Bialkowska A, Bialkowski K, Gerschenson M, Diwan BA, Jones AB, et al. (2000) Oxidative DNA damage in fetal tissues after transplacental exposure to 3'-azido-3'-deoxythymidine (AZT). Carcinogenesis 21: 1059-1062.

14. Olivero OA, Shearer GM, Chougnet CA, Kovacs AA, Landay AL, et al. (1999) Incorporation of zidovudine into leukocyte DNA from HIV-1positive adults and pregnant women, and cord blood from infants exposed in utero. AIDS 13: 919-925.

15. Meng Q, Fasco MJ, Bellisario R, Kaminsky L, Pass KA, et al. (2001) Plasma and cellular markers of 3'-azido-3'- deoxythymidine metabolism as indicators of DNA incorporation of $3^{\prime}$-azido-3'-deoxythymidine metabolism as indicators of DNA incorporation of 3'-azido-3'deoxythymidine in cord blood lymphocytes from infants exposed in utero. Environ Mol Mutagen 37: 53-58.

16. Slamenová D, Horváthová E, Bartková M (2006) Nature of DNA lesions induced in human hepatoma cells, human colonic cells and human embryonic lung fibroblasts by the antiretroviral drug 3'-azido-3'deoxythymidine. Mutat Res 593: 97-107.

17. Gogu SR, Beckman BS, Agrawal KC (1992) Amelioration of zidovudineinduced fetal toxicity in pregnant mice. Antimicrob Agents Chemother 36: $2370-2374$

18. Applewhite-Black LE, Dow-Edwards DL, Minkoff HL (1998) Neurobehavioral and pregnancy effects of prenatal zidovudine exposure in Sprague-Dawley rats: preliminary findings. Neurotoxicol Teratol 20: 251-258.

19. Tuomala RE, Shapiro DE, Mofenson LM, Bryson Y, Culnane M, et al. (2002) Antiretroviral therapy during pregnancy and the risk of an adverse outcome. N Engl J Med 346: 1863-1870.

20. Cotter AM, Garcia AG, Duthely ML, Luke B, O'Sullivan MJ (2006) Is antiretroviral therapy during pregnancy associated with an increased risk of preterm delivery, low birth weight, or stillbirth? J Infect Dis 193: 1195-1201.

21. Calamandrei G, Venerosi A, Branchi I, Alleva E (1999) Effects of prenatal zidovudine treatment on learning and memory capacities of preweanling and young adult mice. Neurotoxicology 20: 17-25. 
Citation: Chongtham R, Bhattacharyya A, Kumar M (2014) Histopathological Changes in Multiple Fetal Tissues Exposed In-Utero to Zidovudine. J AIDS Clin Res 5: 373. doi:10.4172/2155-6113.1000373

Page 5 of 5

22. Venerosi A, Cirulli F, Lil'p IG, Fiore M, Calamandrei G, et al. (2000) Prolonged perinatal exposure to AZT affects aggressive behaviour of adult CD-1 mice. Psychopharmacology (Berl) 150: 404-411.

23. Sieh E, Coluzzi ML, Cusella De Angelis MG, Mezzogiorno A, Floridia M, et al. (1992) The effects of AZT and DDI on pre- and postimplantation mammalian embryos: an in vivo and in vitro study. AIDS Res Hum Retroviruses 8: 639-649.

24. Busidan Y, Shi X, Dow-Edwards DL (2001) AZT distribution in the fetal and postnatal rat central nervous system. J Pharm Sci 90: 1964-1971.

25. Blanche S, Tardieu M, Rustin P, Slama A, Barret B, et al. (1999) Persistent mitochondrial dysfunction and perinatal exposure to antiretroviral nucleoside analogues. Lancet 354: 1084-1089.
26. de la Asunción JG, del Olmo ML, Sastre J, Pallardó FV, Viña J (1999) Zidovudine (AZT) causes an oxidation of mitochondrial DNA in mouse liver. Hepatology 29: 985-987.

27. Ewings EL, Gerschenson M, St Claire MC, Nagashima K, Skopets B, et al. (2000) Genotoxic and functional consequences of transplacental zidovudine exposure in fetal monkey brain mitochondria. J Acquir Immune Defic Syndr 24: 100-105.

28. Kakuda TN (2000) Pharmacology of nucleoside and nucleotide reverse transcriptase inhibitor-induced mitochondrial toxicity. Clin Ther 22: 685-708. 